\title{
Research Paper: Analysis of the Effect of Empowering Women on the Motivation of Creating and Developing Rural Businesses (Case Study: Kermanshah Province, Iran)
}

\author{
Mohammad Akbarpour $^{1^{*}}$, Soheyla Bakhtar ${ }^{2}$ \\ 1. Department of Geography, Razi University, Kermanshah, Iran. \\ 2. University of Tabriz, Tabriz, Iran.
}

\begin{tabular}{|c|c|}
\hline $\begin{array}{l}\text { Use your device to scan } \\
\text { and read the article online }\end{array}$ & Citation: Akbarpour, M., \& Bakhtar, S. (2020). Analysis of the Effect of Empowering Women on the Motivation of Creating \\
\hline atping & $\begin{array}{l}\text { and Developing Rural Businesses (Case Study: Kermanshah Province, Iran). Journal of Sustainable Rural Development, 4(2), } \\
\text { 121-134. https://doi.org/10.32598/JSRD.4.2.2 }\end{array}$ \\
\hline aptids & doi": https://doi.org/10.32598/JSRD.4.2.2 \\
\hline
\end{tabular}

Article info:

Received: 12 July 2019

Accepted: 08 Dec. 2019

Keywords:

Empowering Women, Rural Businesses, Rural Development, Sustainable Development, Province of Kermanshah

\section{A BSTRACT}

Purpose: Empowering rural women is one of the policies and strategies used to develop rural businesses because rural businesses can create employment and reduce unemployment, resulting in increased self-confidence and empowerment of the villagers. Regarding the importance of this issue, the present study aimed at investigating the effect of empowering women on the motivation of creating and developing rural businesses.

Methods: This paper is an applied study in terms of purpose and descriptive-analytic in nature. The statistical population consists of 504 samples selected from 84 villages in 26 rural districts. The data were collected using bibliographic and field study methods. To analyze the data, a compiled framework based on the previous studies was used, which was composed of 5 indexes of empowerment in 50 items and rural business in 14 items.

Results: The results showed that empowering women was effective in motivating them to create and develop rural businesses as the result of multivariate regression indicated that the empowerment variables account for .378 of changes in rural businesses. The results of the KODAS technique used to assess the motivation of women to develop rural businesses showed that rural women are in different business motivation situations so that in terms of motivation to develop rural businesses, only women in Sarchaqa and Seyed Ayaz were more favorable than other villages.

Conclusion: Women play an important role in the family and since villages are suitable environments for the development of non-agricultural, production and service activities, they can provide the appropriate conditions for creating business and employment for women. 


\section{Introduction}

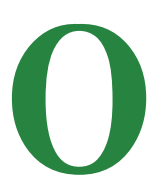

ne of the signs of development in each society is the business area set and managed by the female entrepreneurs. Women's participation in economic activities has played an important role not only in the development of women but also in the process of economic and social development in society. Many development policies, all over the world, intend to improve women's position because they experience various social, economic, problems, etc. (Pradhan et al, 2019). Undoubtedly, the gender gap is more prominent in rural areas, hindering women to participate and influence (Bleak \& Michelitch, 2018). These inequalities, in long term, not only result in imbalances but also affect the population structure, fruitfulness, and overall well-being of rural people. In this context, studying the strategies to enhance women's empowerment and their comprehensive development to narrow the gender gap and increase the efficiency of production and social-economic sustainable development in rural areas is of great importance (Han et al, 2019). Thus, empowering women is considered to be a major need to monitor progress and achieve the goals of sustainable development, and is associated with various issues such as eliminating poverty and hunger and improving health, increasing savings, reducing inequality, and distributing wealth, which lead to long-term growth (Portes et al, 2019). Women are often considered mobility deprived, which has an impact on their quality of life and the assignment of caring responsibilities to women entail meeting specific needs and wants (Noack, 2010).

Therefore, empowering women is rooted in issues such as human development and gender justice through concepts including choice, power, control over life, decision-making ability, and life skills. Thus, increasing women's abilities and skills can have an important role in improving the rural household conditions and, as a result, rural life (Chant, 2003).

Empowering rural women is one of the concepts of business and one of the strategies and policies used to develop rural businesses because rural businesses can result in high self-confidence and empowerment of the villagers besides creating jobs and reducing unemployment (Gibosen \& Olivio, 2006). The strategies of rural economic development pay more attention to the entrepreneurs who start and develop new businesses rather than attracting big businesses (Deller et al, 2019). In this sense, the politicians use it as a key strategy to prevent the evacuation of rural areas, and women consider it as a career option that can provide them with income and independence (Akqun et al., 2010). Women's business causes many benefits in terms of earning potential and prevention of risks (Hamwi \& Lizarralde, 2017; Li \& Shen, 2019). In addition, the economic evaluation shows that such occupations have acceptable economic justification and can increase rural income by up to $57 \%$ (Huggblade et al, 2009).

Regarding the increasing diversity and access to economic activities in rural areas, it is of greater importance to understand the elements of rural businesses (Korsgaard et al., 2015; Dubois, 2016; Bosworth \& Turner, 2018). Rural businesses encompass opportunities for innovation (Hjalager \& Kwiatkowski, 2018: 218), cause changes in employment of rural areas, and offer a variety of livelihood options in addition to agriculture (Greenberg et al., 2018). Since the rural economy does not depend only on agriculture, initial research on the elements and reliability of rural businesses has been expanded and there are different limitations such as lack of fundamental infrastructure, low level of education, and low access to credit and technology (Carter et al, 2019). On the other hand, the weaknesses and shortcomings in rural economies have triggered efforts for economic development, innovation, and improving productivity (OECD, 2016; Phillipson et al, 2019).

In most developing countries, including Iran, women play a key role in rural communities. However, a high percentage of rural women suffer from a lack or shortage of opportunities to access education, employment, and social services, their capabilities are underestimated in improving the lives of their families, community, and of their own (Koeing et al., 2003). Therefore, one of the goals of development in Iran is reducing unemployment and potential enhancement of women's empowerment because many issues such as unemployment, migration, marginalization, and poverty are originated from the underdevelopment of villages and high rates of rural unemployment. According to the 2016 report of the Iranian Census Bureau, women comprise $49.6 \%$ of the population of the country, among whom $13 \%$ are active workforce in the cities and $40 \%$ are workforce in the villages, excluding those who make a living at home through self-employment. On the other hand, a significant number of women in Iran are educated and skilled applicants, among whom only $16.3 \%$ are economically active as reported by the World Bank in 2011 (World Bank, 2011). According to the 2016 census, $24.51 \%$ of the population in the province of Kermanshah lived in villages, of which about $14 \%$ were women. Regarding the statistics released by the Ministry of Cooperatives, Labor, and Social Affairs, the unemployment rate in this 
province is above 3 percent and it is ranked among the cities with the highest rate of unemployment and this rate includes rural areas as well as rural women, and hence, the employment and business of this part of the population of the province should not be ignored because creating opportunities for employment of this part of population leads to changes in economic and social conditions of the province. The studies, nevertheless, showed that women face many problems when starting a business since people in the rural areas have more traditional attitudes towards gender, the assessment and management skills among the rural women are lower than those of urban women, and access to non-local capital is more difficult, all resulting in negative effects. Thus, it is required to consider the mentioned issues as well as the different aspects of women's empowerment and measure it to create a business. These factors must be examined using a comprehensive perspective and valid methodology. Considering the importance of this issue, the present study aimed at investigating the effect of empowering women in rural areas of Kermanshah on the motivation of creating rural businesses to:

- Examine the impact of indexes of empowering women on creating business

- Examine the motivation of creating business by women in rural areas

\section{Literature Review}

Concerns regarding the inclusion of women in the poorest group of the poor led to various approaches such as empowerment, which is considered by the UN in a broader sense as one of the key goals of the Third Millennium (Khan \& Bibi, 2011). The two UN world conferences in 1980 and 1985 emphasized political and social issues but in the third conference in 1987, the main focus was on the gender equality and empowerment of women through socio-economic development; the subsequent important reports by the UN agencies emphasized this issue (Topal, 2019), which was finally considered as the main goal of sustainable development plans for 2030 (United Nations, 2015).

Empowerment emphasizes gaining more control on life through increasing awareness and is considered as a mechanism that enables people, organizations and societies to control the issue (Quaedvlieg et al., 2014) and makes people aware of the dynamics of power in their work and life in order to develop the skills and capacities needed to gain acceptable and reasonable control over their lives (Mudege et al., 2015). Moreover, this concept emphasizes enhancing an individual's power over time, by which people, organizations, and communities learn to make a close relationship between their goals and the sense of achieving them as well as gaining access to and control over resources (Ngwenya et al., 2019). Empowerment is an element of increasing assets and income and increasing decision-making capacity through the optimal use of time (Bain, 2018), since providing more opportunities for women is a positive and important goal that cannot be left to top-down solutions of national or international development, but it should be extracted from a common ideology focused on women's rights and empowerment (Waltz, 2016). In the Beijing Declaration (1990) that emphasized the principle of equality in all social areas, women's empowerment was considered as a means for their participation in the decision-making process and access to power to gain equality, development, and peace (Charlier et al., 2006). In this context, there are debates all over the world on assigning credit to women, which is considered to be the key to sustainable social and economic development in the 21 st century (Ganle et al., 2014). In this context, empowering women that includes decision-making ability, choice, self-organization, and participation, considers creating personal, group, and collective power to change the existing situation, and regards it as a dynamic process that enables women to understand and criticize the realities surrounding them and relying upon their abilities and power, try to change the undesirable conditions (Rezai $\&$ Zarei, 2014). In this sense, empowering women is a social phenomenon and since social phenomena are not one-dimensional, empowering women depends on various internal factors such as physical and mental conditions, and economic situation as well as external factors such as social structures (Kaldi \& Salahshoori, 2012).

Since rural women have less access to key agricultural resources such as land, workforce, technology, animal husbandry, and education (Ransom \& Bain, 2011; Bain, 2018), rapid changes in information technology and decline in the economic significance of agriculture in rural areas have attracted women's attention to developing rural businesses (Korsgaard et al., 2015; Bosworth \& Turner, 2018), which is applied as a recognized method to facilitate women's empowerment in emerging economies (Ajjan et al., 2014; Crittenden, 2019). Besides improving the women's bargaining ability, it makes them economically independent and increases their control over their income from assets (Johanson et al., 2016). It, on the other hand, creates a sense of hope and vitality in the community by providing job opportunities; some experts asserted that business development is the most important strategy for rural development in the 
Third World (Gibosen \& Olivio, 2006) and considered it as an influential means for empowerment (Carr, 2003; Ngwenya et al., 2019). Thus, understanding the qualities of a rural business, due to growing diversity and access to economic activities in rural areas, is of great importance (Dubois, 2016). Rural businesses contain different features such as local relationships and developmental activities (Sofer \& Saada, 2016). It can be said that business is not merely business in a rural location. Regarding increasing communication and interdependence between urban and rural economies (Moyes et al., 2015), it encompasses agricultural development and the related activities, i.e. handicrafts and rural industries, socio-economic infrastructures, social services, and the relevant facilities, and above all, human resource development in rural areas (Papzan et al., 2011).

There are various studies on women's empowerment, such as the study by Koolaei and Taheri (2011). They studied the effect of empowering women in rural development in Iran and found that the more empowered women are, their political participation, productivity, and social role will increase. Furthermore, Sa'di et al. (2014) studied the effect of domestic businesses on rural women's social empowerment and concluded that social empowerment has a significant relation with the type of business and social empowerment has a high impact. A'zami et al. (2016) evaluated the effect of the components of cognitive empowerment on women's social participation in the city of Kangavar and concluded that the components of empowerment are significantly different, and there is a significant association between age, relationships, using the Internet, newspapers and mass media and women's social participation. Kazemi et al. (2018) studied the effect of social capital on rural women's cognitive empowerment in Salmas. They showed that social capital has a positive and significant effect on women's empowerment. Farrashi et al. (2019) examined the effective factors on empowering rural women who received microcredits in the city of Nahavand. They concluded that individuals' attitudes towards microcredits, the supervision of the lender on loan utilization, loan utilization in empowering activities, educating the lender, and the total amount of loan are regarded as effective factors in empowering women.

Sharma and Kanta Varma (2008) found that participation in income-generating activities is one of the factors of empowering women. Chaudhry \& Nosheen (2009) found, in their study entitled "the effective factors on empowering rural women in the south of Panjab", that the family participation rate and social and cultural norms affect empowerment. Abraham (2011), in a study aiming at measuring social empowerment, concluded that older members are more empowered. Rani Mohanty et al. (2013) showed that empowering women through economic independence is provided via the successful functions of microbusinesses, having a greater impact on social and economic empowerment. Mitra and Kundu (2012), in a study aiming at evaluating empowerment through social capital, found that social capital plays an important role in empowering rural women. Waltz (2016) conducted a research to study rural women's empowerment in the south of Brazil and concluded that rural women's empowerment and employment are accessible by modeling urban employment for women through institutionalizing these plans for gender dynamics and equality. Finally, Topal (2019) studied economic reform to empower women in Saudi Arabia and found that empowering women in Saudi Arabia has been used as a goal and code to increase competition in the economy of this country based on the integration of the international economy.

\section{Introducing the region}

The province of Kermanshah is situated in western Iran, which is bound on the west by Iraq and on the three other sides by Lorestan, Kordestan, Ilam, and Hamedan. It lies between $36^{\circ}$ and $33^{\circ}$ to $15^{\circ}$ and $35^{\circ} \mathrm{N}$ latitude and $24^{\circ}$ and $45^{\circ}$ to $30^{\circ}$ and $48^{\circ} \mathrm{E}$ longitude. According to the latest census in 2016, the population includes 1952434 people, of which 1468615 people live in cities and 478444 people in villages. This province is divided into 14 towns, 27 districts, 26 cities, 85 villages, and 3172 rural districts (Population and Housing Census, 2016). Figure 1 shows the geographic location of Kermanshah in Iran:

\section{Methodology}

The statistical population of the present study consists of 230640 rural women living in 85 rural districts of the province of Kermanshah. Due to broad area, high population size, and lack of access to all regions, the cluster sampling method was used; in the first stage, 2 rural districts from each town and 3 villages from each rural district and 6 people from each village were selected and totally 504 people from 84 villages in 26 rural districts were selected to complete the questionnaire in 14 towns. Selecting samples in each village, the systematic random sampling method was used. 


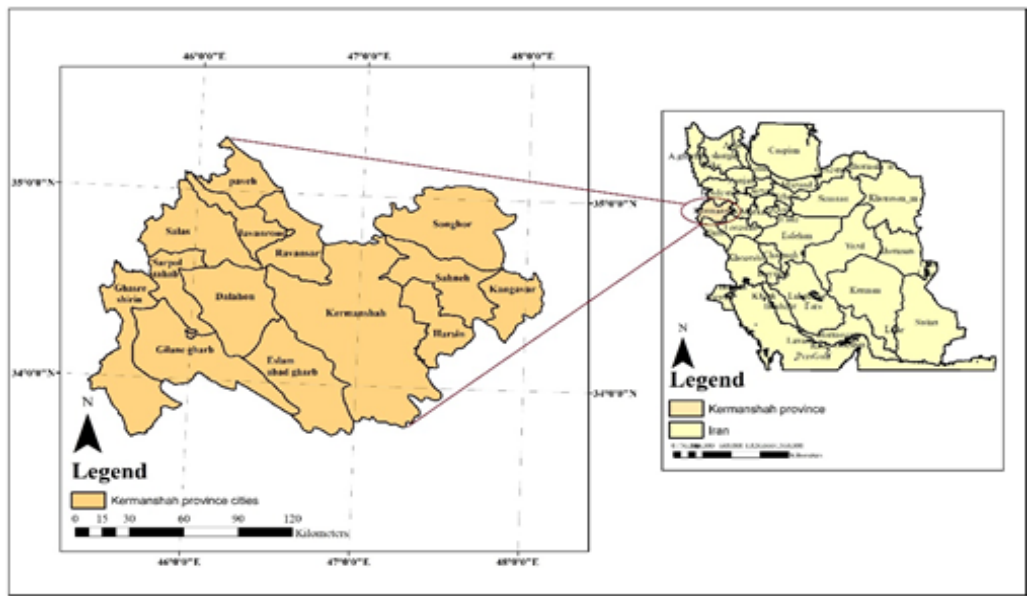

Figure 1. Geographic location of Kermanshah in Iran

Bibliographic method (the introductory part of the research) and field study (questionnaire) were used to collect data. Considering the objective of this study, selecting the framework of basic indexes of the research is of great importance. Therefore, the indexes used in this study were selected from the previous studies after examining the theoretical literature. Thus, for the variable of empowering women, 5 indexes were used: personal empowerment and cognition (16 indicators), social and cultural empowerment (13 indicators), technical empowerment ( 7 indicators), economic empowerment (9 indicators), and educational empowerment (6 indicators). Moreover, 14 indicators were used for the variable of business motivation (Table 1).

The questionnaire was primarily designed with closeended questions in the form of a 5-point Likert Scale (very high, high, moderate, low, and very low). Making necessary changes and revisions, the validity of the questionnaire was confirmed by the experts. The reliability of the questionnaire was measured by distributing 30 questionnaires as a pre-test in the region under study using Cronbach's alpha and the total reliability was estimated as 0.815 , indicating proper coordination among the items (Table 2).

To analyze data, descriptive and inferential methods were used. In descriptive statistics, the mean and standard deviation were used, and multivariate regression was used in the inferential statistics by using SPSS to predict the effect of the independent variable on the dependent variable. In this method, the desirability of alternatives is determined by using two measures. The primary measure is related to the Euclidean distance of alternatives from the negative ideal. Using this type of distance requires an 12-norm indifference space for cri- teria. The secondary measure is the Taxicab distance which is related to the 11-norm indifference space. It is clear that the alternative which has greater distance from the negative-ideal solution is more desirable. In this method, if we have two alternatives that are incomparable according to the Euclidean distance, the Taxicab distance is used as a secondary measure. Although the 12-norm indifference space is preferred in the CODAS, two types of indifference space could be considered in its process. Suppose that we have $n$ alternatives and $m$ criteria. The steps of the proposed method are presented as follows:

Step 1. Construct the decision-making matrix (x).

Step 2. Calculate the normalized decision matrix.

Step 3. Calculate the weighted normalized decision matrix.

Step 4. Determine the negative-ideal solution.

Step 5. Calculate the Euclidean and Taxicab distances of alternatives from the negative-ideal solution, as follows:

$$
\begin{aligned}
& \mathrm{E}_{\mathrm{i}}=\sqrt{\hat{a}_{\mathrm{j}=\mathrm{i}}^{\mathrm{m}}\left(\mathrm{r}_{\mathrm{ij}}-\mathrm{ns}_{\mathrm{j}}\right)^{2}} \\
& T_{i}=\sum_{j=i}^{m}\left|r_{i j}-n s_{j}\right|
\end{aligned}
$$

Step 6. Construct the relative assessment matrix, as follows:

$$
\mathrm{h}_{\mathrm{ik}}=\left(\mathrm{E}_{\mathrm{i}}-\mathrm{E}_{\mathrm{k}}\right)+\left(\varphi\left(\mathrm{E}_{\mathrm{i}}-\mathrm{E}_{\mathrm{k}}\right) \times\left(\mathrm{T}_{\mathrm{i}}-\mathrm{T}_{\mathrm{k}}\right)\right)
$$


Table 1. List of indexes and indicators

\begin{tabular}{|c|c|c|c|}
\hline Variable & Index & Indicator & Source \\
\hline \multirow{5}{*}{ 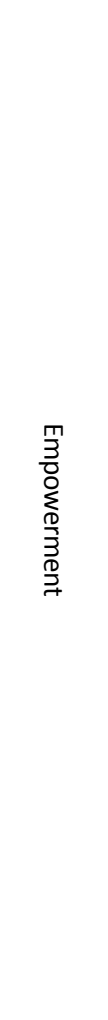 } & $\begin{array}{l}\text { Individual and } \\
\text { cognitive }\end{array}$ & $\begin{array}{c}\text { Leadership, motivation for independence, need for success, self- } \\
\text { confidence, and self-esteem, the tendency for creativity, ability } \\
\text { to take risks, being open to criticism, ambiguity-tolerance (ability } \\
\text { to face unpredicted events), determination and hardworking, } \\
\text { discipline and order, full attention to work, insisting on problem- } \\
\text { solving, accountability, social acceptance, understanding values, } \\
\text { accuracy in work }\end{array}$ & $\begin{array}{l}\text { Khosravipour \& Pourjavid, 2017; } \\
\text { Gheisari, 2012; Spritzer, } 1995\end{array}$ \\
\hline & $\begin{array}{l}\text { Social and } \\
\text { cultural }\end{array}$ & $\begin{array}{l}\text { Participation in charities, participation in constructive activities, } \\
\text { attending meetings, absence of harassment, membership in rural } \\
\text { organizations, increasing communication and intimacy among } \\
\text { rural women, others' positive attitude toward entrepreneur- } \\
\text { ship, traditions, norms and existing beliefs in the village, families' } \\
\text { customs and beliefs, men's beliefs about women's management } \\
\text { abilities, motivation for gaining social status, doing collective work, } \\
\text { increasing women's participation and activities in decision-making }\end{array}$ & $\begin{array}{l}\text { Dadvarkhani et al., 2013; Rezaei } \\
\text { \& Zare'ei, 2014; Asqari Lafmajani, } \\
\text { 2016; Khosravipour \& Pourjavid, } \\
2017\end{array}$ \\
\hline & Technical & $\begin{array}{l}\text { Using the experience of local entrepreneurs, the infrastructural } \\
\text { facilities needed for business establishment, transportation } \\
\text { expansion and development, providing women's access to ICT, } \\
\text { awareness of potentials and contexts in individuals and regions, } \\
\text { innovation, using local knowledge }\end{array}$ & $\begin{array}{l}\text { Khosravipour \& Pourjavid, 2017; } \\
\text { Maleki, 2007; Gheisari, } 2012\end{array}$ \\
\hline & Economic & $\begin{array}{l}\text { Knowledge about land legal issues attempts to open a bank ac- } \\
\text { count, having budgeting skills, improving conditions to purchase } \\
\text { agricultural tools, access to capital, access to family workforce, } \\
\text { access to the product market, skills in family production activities, } \\
\text { interest in creating jobs in the village }\end{array}$ & $\begin{array}{c}\text { Safavi et al., 2014; Asqari Lafma- } \\
\text { jani, 2016; Maleki, } 2017\end{array}$ \\
\hline & Educational & $\begin{array}{c}\text { Access to schools, using media and journals in the field of busi- } \\
\text { ness, training entrepreneurial skills, providing rural women } \\
\text { with appropriate technical consultation and expertise, holding } \\
\text { vocational and business education and training courses, risk-taking } \\
\text { culture }\end{array}$ & $\begin{array}{c}\text { Khosravipour \& Pourjavid, 2017; } \\
\text { Maleki, } 2017\end{array}$ \\
\hline Rural & usinesses & $\begin{array}{l}\text { X1. Good business plan, X2. Experience and proficiency, X3. } \\
\text { Appropriate market access, X4. Financial credit, X5. Appropriate } \\
\text { business environment, X6. Sense of competition, X7. Motivation } \\
\text { for business, X8. Creativity and entrepreneurship, X9. Communicat- } \\
\text { ing business skills, X10. Good local market, X11. Access to capital } \\
\text { and financial resources, X12. Enjoying tax deduction in building } \\
\text { workshops, X13. Marketing for the products, X14. Entrepreneurial } \\
\text { loans }\end{array}$ & $\begin{array}{l}\text { Najafi \& Safa, 2014; Mirlatifi et } \\
\text { al., 2014; Bowen et al., 2009; } \\
\text { Kanchena et al., 2013; Sa'di \& } \\
\text { Heidari, 2013; Agahi et al., 2012; } \\
\quad \text { Sharifzade et al., 2013; Os- } \\
\text { utaiman et al., 2012; Anthopou- } \\
\text { lou, 2010; Mirlatifi et al., 2014; } \\
\text { Jamshidi et al., } 2014\end{array}$ \\
\hline
\end{tabular}

Table 2. The reliability coefficient of different parts of the questionnaire

\begin{tabular}{ccccccc}
\hline Index & \multicolumn{1}{c}{ Individual and cognitive } & Social & Technical & Economic & Educational & Business \\
\hline Alpha value & 0.882 & 0.810 & 0.721 & 0.751 & 0.773 & 0.868 \\
\hline Source: the findings of the study, 2019 & & & & & &
\end{tabular}

Score (Hi). The alternative with the highest $\mathrm{Hi}$ is the best choice among the alternatives.

Finally, GIS 1/3/10 ARC software was used to draw maps. Figure 2 shows the conceptual model of research.

\section{Findings}

The respondents to the questionnaire distributed among the rural women in Kermanshah were mostly (37.4\%) in the age range of $36-45$ years old. In terms of education (illiterate, elementary school, diploma, associate degree, bachelor, and higher), most respondents $(31.9 \%)$ had an associate degree. Besides, $43.1 \%$ were engaged in agriculture and related activities.

Results from the descriptive findings of the studied indicators show the percentage of respondents in the index of personal and cognitive empowerment, 11/25\% of people were the very low level of response And More response rate Was at a high level with 28/45, The mean and standard deviation of this index were $3 / 07$ and $0 / 66$, re- 
spectively. In relation to the social empowerment index Maximum response rate With 11/29 at a very high level And the lowest response rate Too little option, It was $15 / 1$. The mean of this index was $3 / 28$ and its standard deviation was estimated to be $0 / 62$. In the Technical Empowerment Index, The lowest response rate to the option is very low at $12 / 1 \%$ And the highest response rate to the average option was $30 / 15$. The mean of this index was $2 / 85$ and its standard deviation was $0 / 67$. Also in the economic empowerment index, It also had a very low option with 13/2 the lowest number of respondents The average option with $27 / 15$ had the highest number of respondents. The mean of this index was 3 and its standard deviation was estimated to be $0 / 66$. In the Educational Empowerment Index, the High option with 18/25 has the most responsiveness And the low option with 15/25 had the least responsiveness. The mean of this index was $3 / 23$ and its standard deviation was 0/69 (Table3).
Regarding the purpose of the study, i.e. investigating the effect of the indexes of empowering women on the motivation of developing rural businesses, multivariate regression test was used to determine the contribution of each index in predicting the dependent variable of business. As Tables 4 and 5 indicate, all indexes of empowering women had a positive effect on the motivation of developing rural businesses; the educational index with a beta coefficient of 0.616 had the highest effect and accounted for 0.378 of the total variance of business. The social empowerment index (0.611), economic index (0.572), and individual and cognitive index with a beta coefficient of 0.547 were in the following ranks. Finally, the technical empowerment index with a beta coefficient of 0.506 was in the lowest rank and predicted only 0.254 of the total variance of business.

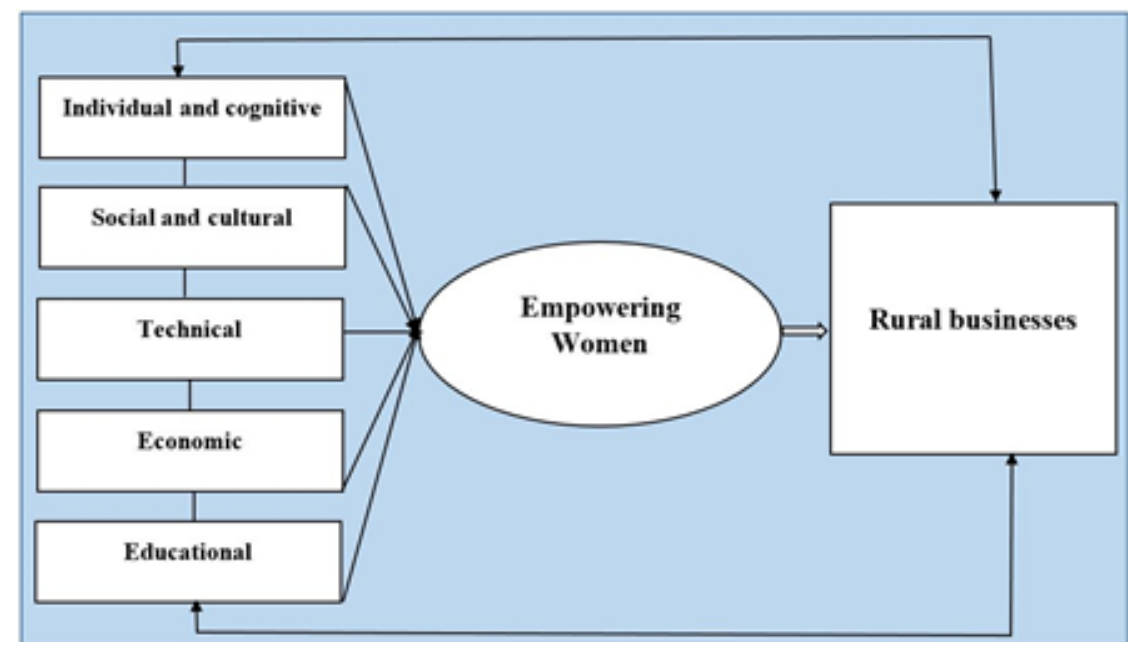

Figure 2. Conceptual Model of Research

Table 3. Descriptive findings of the research

\begin{tabular}{|c|c|c|c|c|c|c|c|}
\hline \multirow[t]{2}{*}{ Index } & very Low & Low & sedium & Much & $\begin{array}{l}\text { Very } \\
\text { much }\end{array}$ & Average & $\begin{array}{l}\text { Standard } \\
\text { deviation }\end{array}$ \\
\hline & \multicolumn{7}{|c|}{ Percentage of respondents } \\
\hline $\begin{array}{l}\text { Individual and cognitive } \\
\text { empowerment }\end{array}$ & 11.25 & 14.31 & 18.25 & 28.45 & 28.1 & 3.07 & 0.66 \\
\hline Social empowerment & 15.1 & 16.1 & 17.15 & 22.65 & 29.11 & 3.28 & 0.62 \\
\hline Technical empowerment & 12.1 & 22.19 & 30.15 & 20.35 & 15.25 & 2.85 & 0.67 \\
\hline Economic empowerment & 13.2 & 18.25 & 27.15 & 25.15 & 16.25 & 3 & 0.66 \\
\hline Educational empowerment & 17.15 & 15.25 & 21.15 & 25.18 & 21.75 & 3.23 & 0.69 \\
\hline
\end{tabular}


Table 4. The results of multivariate regression coefficient in studying the effects of empowerment on the motivation of developing rural businesses

\begin{tabular}{ccccc}
\hline Index & $\begin{array}{c}\text { Regression coef- } \\
\text { ficient }\end{array}$ & $\begin{array}{c}\text { coefficient of deter- } \\
\text { mination R2 }\end{array}$ & $\begin{array}{c}\text { The adjusted coefficient of } \\
\text { determination }\end{array}$ & Sig \\
\hline Individual and cognitive empowerment & 0.547 & 0.300 & 0.298 & 0.000 \\
\hline Social empowerment & 0.611 & 0.373 & 0.371 & 0.000 \\
\hline Technical empowerment & 0.506 & 0.256 & 0.254 & 0.000 \\
Economic empowerment & 0.572 & 0.327 & 0.325 & 0.000 \\
\hline Educational empowerment & 0.616 & 0.379 & 0.378 & 0.000 \\
\hline Source: The findings of the study, 2019 & & & & JSRD
\end{tabular}

Table 5. The results of multivariate regression coefficient

\begin{tabular}{|c|c|c|c|c|}
\hline \multirow{2}{*}{ Index } & \multicolumn{2}{|c|}{ Nonstandard coefficients } & \multirow{2}{*}{$\begin{array}{c}\text { Standard coefficients } \\
\text { Beta }\end{array}$} & \multirow{2}{*}{$\mathbf{T}$} \\
\hline & B & S.E & & \\
\hline Intercept (constant number) & 1.885 & 0.123 & -- & 15.343 \\
\hline Individual and cognitive empowerment & 0.501 & 0.039 & 0.547 & 12.803 \\
\hline Social empowerment & 0.598 & 0.040 & 0.611 & 15.093 \\
\hline Technical empowerment & 0.459 & 0.040 & 0.506 & 11.491 \\
\hline Economic empowerment & 0.521 & 0.038 & 0.572 & 13.647 \\
\hline Educational empowerment & 0.536 & 0.035 & 0.616 & 15.301 \\
\hline
\end{tabular}

Source: The findings of the study, 2019

After showing the effect of empowerment on the motivation of business, the villages under study were classified based on the variable of business, according to the rural women's attitudes toward motivation of business. In this context, the CODAS decision-making technique was used. Therefore, prior to applying this technique, the indexes were weighted based on Shannon Entropy technique. Table 6 indicates the weight of each indicator of this variable. As demonstrated, any considered indicator has a different weight so that the sum of these indicators should be equal to one. The most weighted indicator is (X3) proper market access.

Positive and negative criteria were identified after construction of the data matrix and weighting each item. 4 items, among the items of business, were negative and incompatible and other items were identified as positive and compatible. To calculate the final value of each item and classify each option, the value of Hik of each item was calculated; therefore, according to the obtained values, the Euclidean and Taxicab distances of alternatives from the negative-ideal solution were also computed (Table 7).

According to the results shown in Table 8, the final value of each option that is equal to the values of $\mathrm{Hi}$, was determined in the final stage. The value of Hi indicates the final value and weight of the villages; higher values are more desirable. The results showed that the women in the village of Sarchaqa (7.85) had higher motivation to create businesses and those living in Pasar (-3.17) and Tin $(-4.30)$ had the lowest level of motivation.

Table 6. The weights of indicators based on Shannon Entropy technique

\begin{tabular}{c|cccccccc}
\hline Indicator code & X1 & X2 & X3 & X4 & X5 & X6 & X7 \\
\hline Weight & 0.07048 & 0.071271 & 0.072803 & 0.07232 & 0.070243 & 0.071584 & 0.071347 \\
\hline Indicator code & X8 & X9 & X10 & X11 & X12 & X13 & X14 \\
Weight & 0.071842 & 0.07072 & 0.071715 & 0.072389 & 0.070633 & 0.07108 & 0.071573 \\
\hline
\end{tabular}

Source: The findings of the study, 2019 
Table 7. Values of $E_{i} \& T_{i}$ for each village

\begin{tabular}{|c|c|c|c|c|c|c|c|c|}
\hline Village & Ei & $\mathrm{Ti}$ & Village & Ei & $\mathrm{Ti}$ & village & $\mathrm{Ei}$ & $\mathrm{Ti}$ \\
\hline Malesorkh & 0.108 & 0.379 & Aqbolaq & 0.109 & 0.384 & Chubine & 0.081 & 0.274 \\
\hline Palangerd & 0.109 & 0.381 & Leilmanj & 0.095 & 0.317 & Islamabad Sofla & 0.098 & 0.350 \\
\hline Tumiyane & 0.107 & 0.367 & Nipahn Abdollah & 0.090 & 0.309 & Halan & 0.085 & 0.305 \\
\hline Hassanabad & 0.115 & 0.415 & Korkharak & 0.111 & 0.384 & Dehlaqin & 0.099 & 0.329 \\
\hline $\begin{array}{l}\text { Baqerabad } \\
\text { Sofla }\end{array}$ & 0.124 & 0.449 & Seyed Saeed & 0.094 & 0.309 & $\begin{array}{l}\text { Cham Botan } \\
\text { Sofla }\end{array}$ & 0.122 & 0.448 \\
\hline Anjirak & 0.128 & 0.467 & Seyed Ayaz & 0.051 & 0.162 & Farash & 0.109 & 0.399 \\
\hline Kaverlovan & 0.140 & 0.493 & Aqaberar & 0.103 & 0.366 & $\begin{array}{c}\text { ChamBbotan } \\
\text { Olya }\end{array}$ & 0.121 & 0.444 \\
\hline Soleimaniye & 0.136 & 0.490 & $\begin{array}{c}\text { Nasrabad Seyed } \\
\text { Ahmad }\end{array}$ & 0.097 & 0.344 & Eshaqvand Olya & 0.122 & 0.448 \\
\hline Chalabad & 0.113 & 0.414 & Aran & 0.078 & 0.268 & Pasar & 0.145 & 0.524 \\
\hline $\begin{array}{c}\text { Chahar zebra } \\
\text { Sofla }\end{array}$ & 0.120 & 0.435 & Dehlor & 0.090 & 0.306 & Cheshme Kabud & 0.104 & 0.381 \\
\hline Chqazard & 0.129 & 0.453 & Qarebonas & 0.107 & 0.360 & $\begin{array}{l}\text { Chamzeresh } \\
\text { Esperi }\end{array}$ & 0.110 & 0.399 \\
\hline Chaqagino & 0.120 & 0.426 & Fesh & 0.081 & 0.261 & Palan Olya & 0.104 & 0.371 \\
\hline Doodan & 0.115 & 0.413 & Hesar & 0.099 & 0.334 & $\begin{array}{c}\text { Chamzereshk } \\
\text { Olya }\end{array}$ & 0.116 & 0.422 \\
\hline Zarduei & 0.129 & 0.463 & Abdultajeddin & 0.092 & 0.321 & Holul & 0.094 & 0.337 \\
\hline Tin & 0.158 & 0.577 & Kolahderaz Sofla & 0.075 & 0.256 & Zamkan Olya & 0.141 & 0.519 \\
\hline Shamshir & 0.117 & 0.422 & Kolahderaz Olya & 0.112 & 0.391 & Mirabad & 0.127 & 0.467 \\
\hline Dorisan & 0.124 & 0.450 & Hoshyarchelleh & 0.101 & 0.350 & Zarde & 0.119 & 0.436 \\
\hline Nasme & 0.124 & 0.454 & Shanqal Khaledi & 0.074 & 0.250 & Darab & 0.098 & 0.351 \\
\hline Bazmirabad & 0.135 & 0.496 & Shisherah & 0.113 & 0.387 & Kooshakri & 0.122 & 0.447 \\
\hline Javanmiri & 0.118 & 0.425 & Galoozi & 0.107 & 0.367 & Harir & 0.091 & 0.334 \\
\hline Donki Ramazan & 0.085 & 0.297 & Biyashush & 0.104 & 0.372 & Sarchqa & 0.014 & 0.021 \\
\hline Tape Maran & 0.101 & 0.360 & Sarrud Olya & 0.120 & 0.420 & Gavdane Khor & 0.088 & 0.319 \\
\hline Tapani & 0.128 & 0.456 & Safiabad & 0.111 & 0.389 & Shabankare & 0.114 & 0.416 \\
\hline Qale' Bahadori & 0.122 & 0.429 & Bivand Sofla & 0.107 & 0.381 & Bonchele & 0.077 & 0.269 \\
\hline $\begin{array}{l}\text { Hezarkhani } \\
\text { Olya }\end{array}$ & 0.103 & 0.344 & Sefidbarg & 0.116 & 0.409 & Ghuri Qale' & 0.090 & 0.324 \\
\hline Charmale Sofla & 0.120 & 0.415 & Bivale & 0.103 & 0.368 & Badrabad & 0.090 & 0.301 \\
\hline Kalgah Zaman & 0.104 & 0.341 & Sartakht & 0.094 & 0.331 & Ghalanche & 0.121 & 0.437 \\
\hline Nokhodtape & 0.134 & 0.478 & Shahpourabad & 0.091 & 0.304 & Sardam & 0.119 & 0.438 \\
\hline
\end{tabular}


Table 8. Classification of the villages based on business

\begin{tabular}{|c|c|c|c|c|c|c|c|c|}
\hline Village & Sarchaqa & Seyed Ayaz & $\begin{array}{l}\text { Shanqal } \\
\text { Khaledi }\end{array}$ & Kolahderaz & Bonchale & Aran & Fesh & Chubine \\
\hline $\mathbf{H}$ & 7.85 & 4.69 & 2.89 & 2.80 & 2.60 & 2.53 & 2.35 & 2.26 \\
\hline Village & $\begin{array}{c}\text { Donki } \\
\text { Ramazan }\end{array}$ & Halan & $\begin{array}{c}\text { Gavdane } \\
\text { Khor }\end{array}$ & Dehlor & Neypahn & Badrabad & Ghori Qale' & $\begin{array}{c}\text { Shahpour- } \\
\text { abad }\end{array}$ \\
\hline $\mathbf{H}$ & 1.99 & 1.97 & 1.63 & 1.60 & 1.60 & 1.58 & 1.47 & 1.46 \\
\hline Village & Harir & Abdultajeddin & Seyed Saeed & Leilmanj & Sartakht & Holul & Nasrabad & Doholqin \\
\hline $\mathbf{H}$ & 1.38 & 1.36 & 1.30 & 1.19 & 1.16 & 1.11 & 0.91 & 0.88 \\
\hline Village & Hesar & Darab & $\begin{array}{l}\text { Islamabad } \\
\text { Sofla }\end{array}$ & $\begin{array}{l}\text { Hoshyar } \\
\text { Chelle }\end{array}$ & $\begin{array}{l}\text { Hezarkhani } \\
\text { Olya }\end{array}$ & Tape Maran & Kalgah Zaman & Aqaberar \\
\hline $\mathbf{H}$ & 0.84 & 0.82 & 0.78 & 0.66 & 0.66 & 0.57 & 0.51 & 0.47 \\
\hline Village & Bivaleh & Palan Olya & Biyashush & $\begin{array}{l}\text { Cheshme } \\
\text { kabud }\end{array}$ & Qarebonas & Tumiyane & Galuzi & Bivan Sofla \\
\hline $\mathbf{H}$ & 0.41 & 0.36 & 0.35 & 0.24 & 0.15 & 0.10 & 0.10 & 0.03 \\
\hline Village & Malesorkh & Palangerd & Aqbolaq & Korkharak & Farash & Chamzereshk & Safiabad & Shisherah \\
\hline $\mathbf{H}$ & 0.00 & -0.09 & -0.12 & -0.20 & -0.23 & -0.26 & -0.29 & -0.36 \\
\hline Village & $\begin{array}{l}\text { Kolahderaz } \\
\text { Olya }\end{array}$ & Chalabad & Doodan & Shabankare & Hassanabad & Sefidbarg & $\begin{array}{c}\text { Chamzereshk } \\
\text { Ollya }\end{array}$ & Shamshir \\
\hline $\mathbf{H}$ & -0.37 & -0.55 & -0.67 & -0.68 & -0.71 & -0.73 & -0.80 & -0.90 \\
\hline Village & Javanmiri & $\begin{array}{c}\text { Charmale } \\
\text { Sofla }\end{array}$ & Sardam & Zarde & Sarrud Olya & Chaqagino & $\begin{array}{c}\text { Chaharzebar } \\
\text { Sofla }\end{array}$ & Qalanje \\
\hline $\mathbf{H}$ & -0.96 & -1.07 & -1.10 & -1.13 & -1.13 & -1.16 & -1.19 & -1.24 \\
\hline Village & $\begin{array}{c}\text { Chambtan } \\
\text { Ollya }\end{array}$ & $\begin{array}{c}\text { Qale' Baha- } \\
\text { dori }\end{array}$ & $\begin{array}{l}\text { Chambtan } \\
\text { Sofla }\end{array}$ & $\begin{array}{l}\text { Eshaqvan } \\
\text { Olya }\end{array}$ & Kooshkari & $\begin{array}{c}\text { Baqerabad } \\
\text { Sofla }\end{array}$ & Dorisan & Nasme \\
\hline $\mathbf{H}$ & -1.32 & -1.33 & -1.38 & -1.38 & -1.41 & -1.49 & -1.52 & -1.52 \\
\hline Village & Tapani & Mirabad & Anjirak & Chaqazard & Zarduei & Nokhodtapeh & Bazmirabad & Soleimaniye \\
\hline $\mathbf{H}$ & -1.83 & -1.84 & -1.86 & -1.89 & -1.95 & -2.36 & -2.45 & -2.49 \\
\hline Village & Kaverlovan & Zamkan Olya & Pasar & Tin & & & & \\
\hline $\mathbf{H}$ & -2.82 & -2.90 & -3.17 & -4.30 & & & & \\
\hline
\end{tabular}

Source: The findings of the study, 2019

\section{Discussion}

In modern societies, especially in rural areas, women play an important role in creating business and their proper performance in this regard has the potential to improve the economic condition of the society. Given the importance of the issue, this study aimed at investigating the effect of empowering women on the motivation of creating and developing rural businesses in the province of Kermanshah. Thus, one of the goals of the Third Millennium is to empower women living in rural areas, and hence, utilizing these women's abilities to take maximum advantage of human force in communities requires accurate identification of their talents and capabilities and fostering their abilities for active and informed participation in providing personal and social well-being. Considering the importance of the issue, the present study aimed at examining and analyzing the ef- fect of empowering women on the motivation of creating and developing rural businesses. It studied the issue in 84 villages in the province of Kermanshah. To do so, 5 indices of women's empowerment containing 51 indicators and the motivation of creating business including 14 indicators were used.

The results of descriptive findings indicated that, according to the female respondents, the mean of women's empowerment was 3.086 and the mean of the motivation of creating business, in accordance with its indicators, was 3.42. Generally, the results obtained from the findings of the present study showed that women as one of the most important human resources can play a key role in the development process of different sectors in any society. The results of the regression test showed that while the role of women's empowerment in business motivation is undeniable, the impact of indexes is not the same. 
Although the association between these two variables is significant, educational empowerment, that is using media and review papers, entrepreneurial skills training, consultation, risk-taking culture, and skill training courses, has a greater effect in creating the motivation of business since rural women's empowerment by skilled and experienced human resources can contribute to increasing motivation for entrepreneurship and creating business among rural women. Women can have an influential role in the business arena. Women's participation in economic activities plays a key role not only in the development of women's capacities and abilities but also in the process of social and economic development of the society. Creating business and establishing organizations for rural women is an important strategy to boost their social and economic growth because they are effective in improving the social condition, promoting income, social justice, and increasing women's social participation as well as producing goods and services. Therefore, improving educational and technical fields can provide the requirements for developing business among rural women, resulting in basic changes in women. Studying the effects of social and cultural empowerment showed that it was ranked as the second influential index on the motivation of business and contributed to increased participation of women in constructions, meetings, and membership in rural organizations, enhancing women's social status. It also influenced men's beliefs about women's management ability and attracted positive attitudes toward entrepreneurial activities. Access to capital and using the family workforce affected providing credit for business. The motivation of creating business and interest in creating jobs in the village contributed to granting entrepreneurial loans; it indicates that women's economic empowerment had impacts on the motivation of creating business. The impact of individual and cognitive empowerment, according to the results of the regression coefficient, showed that this index with regression coefficient of 0.547 had an acceptable impact on the motivation of creating business because the motivation of being independent, need for achievement, tendency to creativity, risk-taking ability, and many other factors are considered as basic factors having a positive impact on creating business, resulting in a good and desirable environment to create business. Technical index with coefficient of 0.506 had a lower impact on the business motivation since inappropriate communicative infrastructures, inadequate use of indigenous knowledge, and ignoring potentials and characteristics of people and rural areas have influenced rural businesses in this regard. The findings of the present study are consistent with those of Koolae and Taheri (2011) who concluded that women's empowerment had an impact on rural development and with those found by A'zami et al. (2016) on the effect of empowerment on women's participation in internal studies. Moreover, these findings are consistent with the findings of Kantaverma (2013) who found that women's empowerment depends on their participation in incomegenerating activities. The findings of Rani Mohanty et al. (2013) that showed empowering women causes gaining economic independence through microbusinesses confirm the findings of the present study. The results found by Waltz (2016) on rural women's empowerment, and those found by Topal (2019) on women's empowerment and economic reforms are in line with the findings of this study.

The results of the KODAS technique used to assess the motivation of women to develop rural businesses show that rural women are in different business motivation situations so that in terms of motivation to develop rural businesses, only women in Sarchaqa and Seyed Ayaz were more favorable than other villages. A desirable business environment enhances the motivation of creating business. On the other hand, entrepreneurial loans and financial credits increase the interest in entrepreneurship in villages. In villages such as Sarchaqa, Seyed Ayaz, Shanqal Khaledi, and some other villages in which motivation was high, the presence of educational environment and women's literacy, as well as training and skill courses in motivating women to create business had positive effects. In these villages, the tendency and interest in creating occupation were higher than the other villages due to their awareness of abilities and capabilities, membership in rural organizations, and collective work.

According to the results, it can be said that empowering women in different fields can be a useful and helpful tool for creating rural businesses, increasing income, sustainability of rural areas, identifying and benefiting from existing opportunities in villages, increasing participation, self-esteem, and many others. Thus, enhancing rural women's empowerment results in the development of rural areas and is considered as an influential policy in fulfilling rural sustainable development because the current changes have made living conditions in the rural areas difficult. In this sense, women's empowerment can contribute to creating business as one of the requirements of developing the rural life since, through creating jobs, it has a great role in reducing poverty and promoting social development, economic development, etc. as one of the major priorities of the macro rural development program. Therefore, it is of great importance to pay attention to women's empowerment as an approach to improve the personal and work life of rural women, which requires 
training in this regard. In this context, women's empowerment can be enhanced through training, skill, competency, and trust, and increasing their effectiveness. In this case, women's sense of worth, thinking power, reliability, right to choose, and control over their life in each activity and process will be increased. It can be said that women play an important role in the family and since villages are a suitable and good environment for the development of non-agricultural, production, and service activities, they can provide the appropriate conditions for creating business and employment for women.

According to the results, the following solutions seem necessary to create and develop rural businesses and make half of the rural population in the province of Kermanshah producers:

- Introducing examples of successful rural entrepreneurs;

- Delivering speeches and holding meetings in the village in order to explain the significance of business in personal and social life;

- Providing financial credit for rural women who are experienced in a skill;

- Providing requirements of a desirable, and safe environment to create and develop rural businesses;

- Providing tax deduction to build workshops for rural women;

- Communicating business skills in rural communities in order to make extensive activities and employment;

- Increasing women's awareness of issues such as their abilities, their rights in the society, access to social and economic opportunities through educational programs and courses can result in increasing women's participation in programs and activities at the regional level;

- Since most women had a diploma or a lower degree, it is suggested to authorities to take required actions to help them to continue their education by establishing cultural and educational facilities and persuading rural families to allow women and girls to study.

\section{Acknowledgements}

This research did not receive any specific grant from funding agencies in the public, commercial, or not-forprofit sectors.

\section{Conflict of Interest}

The authors declared no conflicts of interest.

\section{References}

Abraham, J. (2011). Measurement of social empowerment of farmers in SHGS: Evidence from India. International NGO Journal. 6(12), 255-261.

Agahi, H; Mirakzade, A.A; Taqibeigi, M. (2013). Prioritizing the Influential Factors on Developing the Rural Women's Home Jobs, Woman and Society, 3rd year, no. 3, pp. 181-201.

Ajjan, H., Beninger, S., Mostafa, R., \& Crittenden, V. L. (2014) Empowering women entrepreneurs in emerging economies: A conceptual model. Organizations and Markets in Emerging Economies, 5(9), 16-30.

Akqun, A.A., Nijkamp, P., Baycan, T. and Brons, M. (2010). The embeddedness of Entrepreneurs in Rural Areas: A Comparative Rough Set Data Analysis. Tijdschrift voor Economische en Sociale Geografie, 101(5), 538-553.

Anthopoulou, T. (2010). Rural Women in Local Agrofood Production: between Entrepreneurial Initiatives and Family Strategies, A case study in Greece". Journal of Rural Studies, 26, 394-403.

Asqari Lafmajani, S., Shahraki, E., Naderianfar, M. (2016). Barriers to Economic and Social Empowerment of Rural Households, Case Study: Clients Under Support of Imam Khomeini Relief Committee in Sistan, Space Economy and Rural Development, fifth year, no.1, 103-124.

A'zami, M; Ataei, P; Aliabadi, V; Mousivand, M. (2016). Evaluating the Effect of Components of Cognitive Empowerment on Women's Social Participation in Community-based Organizations: Application of Structural Equations, Woman and Society, 7 th year, no. 1, 143-161.

Bain, C., Ransom, E., Halimatusa'diyah, I. (2018). Weak winners' of Women's empowerment: The gendered effects of dairy livestock assets on time poverty in Uganda, Journal of Rural Studies, vol 61, 100-109.

Bleack, J., Michelitch, K. (2018). Is women's empowerment associated with political knowledge and opinions? Evidence from rural Mali, World Development, no 106, 299-323.

Bosworth, G., Turner, R. (2019). Interrogating the meaning of a rural business through a rural capital framework, Journal of Rural Studies, vol 60,1-10. 
Bowen, M., Morara, M., \& Mureithi, S. (2009). Management of business challenges among small and micro enterprises in Nairobi-Kenya. KCA journal of business management, 2(1), 16-31.

Carr, E.S. (2003). Rethinking empowerment theory using a feminist lens: the importance of process. Affilia, vol 18, 8-20.

Carter, M. R., Tjernström, E., Toledo, P. (2019). Heterogeneous impact dynamics of a rural business development program in Nicaragua, Journal of Development Economics, vol 138, 77-98.

Chant, S. (2003). New contributions to the analysis of poverty: methodological and conceptual challenges to understanding poverty from a gender perspective. Santiago: CEPAL U.N., Women and Development Unit.

Charlier, S., Caubergs, L., Malpas, N., Mula Kakiba, E., Beck, D. \& Grown, C. (2006). The women empowerment approach (A methodological guide). Commission on Women and Development (CWD), Retrieved from http:/ / www.dgcd.be

Chaudhry, I. S \& Nosheen, F. (2009). The determinants of women empowerment in southern Punjab (Pakistan): an empirical analysis. European Journal of Social Sciences, 10(2), 216-229.

Crittenden, V, L., Crittenden, W. F., Ajjan, Haya. (2019). Empowering women micro-entrepreneurs in emerging economies: The role of information communications technology, Journal of Business Research, vol 98, 191-203.

Dadvarkhani, F; Malekan, A; Azmi, A; Ahmadi, R. (2013). Comparative Study of Effects of Social Capital on Improving Rural Development, Case Study: Village of Gudin, the city of Kangavar, Spatial Planning, 3rd year, no. 3, 125-144.

Delle, S., Kures, M., Conroy, T. (2019). Rural entrepreneurship and migration, Journal of Rural Studies, vol 66, 30-42.

Dubois, A. (2016). Transnationalising entrepreneurship in a peripheral region - the translocal embeddedness paradigm. Journal of Rural Studies, Vol 46,1-11.

Farrashi, Marziyeh; Rahimian, Mahdi, Gholamrezaei, Saeed. (2019). Analysis of Effective Factors on Empowering the Rural Women Who Received Micro Credits in the City of Nahavand, Woman and Society Quarterly, 10th year, no. 1, 97-120.

Ganle, J. K., Afriyie, K., Segbefia, A. Y. (2014). Microcredit: Empowerment And Disempowerment Of Rural Women In Ghana, World Development, vol 66, 335-345.

Gheisari, H; Shahvali, M; Rezaei Moghaddam, K. (2012). Studying the Cognitive Empowerment of Members of Rural Production Cooperatives in the Province of Fars, Rural Researches, no. 2, 1-20

Gibosen, J., Olivia, S. (2006). The effect of infrastructure access and quality on non-farm enterprises in rural Indonesia. Journal of World Development, vol 12, 28 -36.

Greenberg, Z., Farja, Y., Gimmon, E. (2018). Embeddedness and growth of small businesses in rural regions, Journal of Rural Studies, vol 62, 174-182.

Hamwi, M., Lizarralde, I. (2017). A review of business models towards service-oriented electricity systems. Procedia CIRP, vol 64, 109-114.
Han, W., Zhang, X., Zhanga, Zh. (2019). The role of land tenure security in promoting rural women's empowerment: Empirical evidence from rural China, Land Use Policy, vol 86, 280-289.

Hjalager, A.M., Kwiatkowski, G. (2019). Entrepreneurial implications, prospects, and dilemmas in rural festivals, Journal of Rural Studies, vol 63, 217-228.

Jamshidi, A,R; Jomeini, D; Nazari Sarmazeh, H. (2014). Studying the Driving and Preventive Factors of Rural Women's Entrepreneurship Development, Case Study: Rural Women of Rural District of MiyanKooh in the town of Ardal, Woman and Society, 5th year, no. 1, 75-93.

Johanson, N.L., Kovarik, C., Meinzen-Dick, R., Njuki, J., Quisumbing, A. (2016). Gender, assets, and agricultural development: lessons from eight projects. World Development. Vol 83, 295-311.

Kanchana, R., Divya, J., \& Beegom, A. A. (2013). Challenges faced by new entrepreneurs. International Journal of Current Research and Academic Review. 71-71.

Kazemi, R; Ya'ghubi, J; Naeimi, A. (2018). Analyzing the Effect of Social Capital on Rural Women's Cognitive Empowerment in the City of Salmas, Iranian Agriculture Emitting and Education Sciences, 14th edition, no. 2, 143-159.

Khan, A. R. \& Bibi, Z. (2011). Women's Socio-Economic Empowerment Through Participatory. Pakistan Economic And Social Review, Volume 49, No. 1, 133-148.

Khosravipour, B; Pourjavid, S. (2017). Investigating the Influential Factors on Entrepreneurship Development in Micro Businesses in the city of Islamabad Gharb through Content Analysis Technique, Rural Development Strategies, 4th edition, No. 3, 299-315

Koeing, A. M., Saifuddin, A., Bazle, H. and Mozumder, KH. (2003). Women's Status and Domestic Violence in Rural Bangladesh Individual and Community Level Effects. Demography, 40(2), 269-288

Kaldi, Alireza, Salahshoori, Parvane. (2012). Studying the Effect of Social Support on Women's Empowerment, Journal of Studies of Iranian Social Development, 4th year, no. 4, pp. $7-22$.

Koolaei, E; Taheri, I. (2011). The Effect of Women's Empowerment on Rural Development in Iran, Woman: Rights and Development, 5 th year, no. 1, 50-65.

Korsgaard, S., Muller, S., Tenvig, H. (2015). Rural entrepreneurship or entrepreneurship in the rural - between place and space, International Journal of Entrepreneurial Behaviour \& Research, 21 (1), 5-26.

Li, Ch., Shen, B. (2019). Accelerating renewable energy electrification and rural economic development with an innovative business model: A case study in China, vol 127, 280-286.

Maleki, T; Golparvar, P; Zarifian, Sh. (2017). Preventive Factors of Developing Micro Businesses in Rural Areas, Case Study: the Village of Goviche in the Central Part of Ahar City, the Strategies of Rural Development, 4 th edition, no. 3, 317-331.

Mirlatifi, M.R; Alavizade, A. M; Bedakhsh, Y. (2014). The Pathology of Effects of Developing the Home Jobs in Rural Areas, Rural Research and Planning, 3rd year, no. 5, 1-12. 
Mitra, S. and Kundu, A. (2012). Assessing empowerment through the generation of social capital. International Journal of Business and Social Research (IJBSR), 2(6): 72-84.

Moyes, D., Ferri, P., Henderson, F., Whittam, G. (2015). The stairway to Heaven? The effective use of social capital in new venture creation for a rural business. Rural Stud. no 39, 11-21.

Mudege, N. N., Nyekanyeka, T., Kapalasa, E., Chevo, T., Demo, P. (2015). Understanding collective action and women's empowerment in potato farmer groups in Ntcheu and Dedza in Malawi, Journal of Rural Studies, vol 42, 91-101.

Najafi, B; Safa, L. (2014). Studying the Entrepreneurial Home Businesses and Barriers and Challenges of Developing them in Rural Areas, Entrepreneurship in Agriculture, 1st Edition, no. $2,61-73$.

Ngwenya, P. R., Restrepo, M. J., Fernandez, R., Kaufmann, B. A. (2019). Participatory video proposals: A tool for empowering farmer groups in rural innovation processes?, Journal of $\mathrm{Ru}-$ ral Studies, vol 69, 173-185.

Noack, E. (2010). Are Rural Women Mobility Deprived? - A Case Study from Scotland, sociologia ruralis, vol 51, pp 79-97.

OECD. (2016). OECD Economic Outlook. OECD Publishing, Paris.

Osotimehin, K., Jegede, C., Akinlabi, B. H., \& Olajide, O. (2012). An evaluation of the challenges and prospects of micro and small scale enterprises development in Nigeria.. American International Journal of Contemporary Research, 2(4), 174-115.

Papzan, A.H; Khaldaghi, Kh; Soleimani, Adel. (2011). Evaluating Technical and Vocational Training of Rural Women on Handicrafts, Journal of Women Sociology, 2nd year, no. 3, pp. 21-38.

Phillipson, J., Tiwasing, P., Gorton, M., Maioli, S., Newbery, R., Turner, R. (2019). Shining a spotlight on small rural businesses: How does their performance compare with urban?, Journal of Rural Studies, vol 68, 230-239.

Portes, L. S. V., Atal, V., Torres, M. J. (2019). From households to national statistics: Macroeconomic effects of Women's empowerment, Economic Modelling, vol 79, 286-294.

Pradhan, R., Meinzen-Dick, R., Theis, S. (2019). Property rights, intersectionality, and women's empowerment in Nepal, Journal of Rural Studies,

Quaedvlieg, J., Roca, I. M. G., Ros-Tonen, M. A. F. (2014). Is Amazon nut certification a solution for increased smallholder empowerment in Peruvian Amazonia?, Journal of Rural Studies, vol 33, 41-55.

Rani Mohanty, S., Das, B. and Trupti, M. (2013). Empowerment of Women in Rural Odisha through Microenterprise, IOSR Journal Of Humanities And Social Science (IOSR-JHSS) 12(1), $1-8$.

Ransom, E., Bain, C. (2011). Gendering agricultural aid analysis of whether international development assistance targets women and gender, gender\& society, vol 25, 48-74.

Rezaei, R; Zare'ei, Sh. (2014). Studying the Rural Women's Attitudes toward the effect of the Social Capital Components on Their Empowerment, Case Study: Village of Hassankhan, the City of Gharveh, Woman in Development and Politics, 12th edition, no. 2, 287-304.
Sa'di, H; Heidari, F. (2013). Home Business Cooperatives in the Province of Hamedan, Developing Entrepreneurship, 6th edition, no. $1,87-104$.

Sa'di, H; Jalilian, S, Ya'ghubi, A. (2014). The Effect of Domestic Businesses on Rural Women's Social Empowerment, Woman and Society Quarterly, 5th year, no. 3, 85-106.

Safavi, E; Zamiran, B; Ma'arefvand, M; Arshi, M. (2014). Economic Empowerment of Girls and Women in Africa, Latin America, and the Caribbean Sea, Social Work, 3rd edition, no. $4,3-12$.

Sharifzade, A; Khaje Shokuhi, A.R; Abdullahzade, GH; Sharifi, M. (2014). The Pathology of Rural Family Business Development in the Province of Golestan; Rural Researches, 5th edition, no. 10, 1-24.

Sharma, P ., \& Kanta Varma, Sh. (2008). Women Empowerment through Entrepreneurial Activities of Self Help Groups, Indian Res. J. Ext. Edu. 8 (1), 46-51.

Sofer, M ., Saada, T. (2016). Entrepreneurship of Women in the Rural Space in Israel: Catalysts and Obstacles to Enterprise Development, Sociologia Ruralis, 57 (1), 769-790.

Spritzer, M. (1995). Psychological Empowerment In Work Place, Dimensions, Measurement And Validation, The Academy Management Journal. (38) 5, 1442-1465.

Topal, A. (2019). Economic reforms and women's empowerment in Saudi Arabia, Women's Studies International Forum vol76, 1-8.

United Nations. (2015). Transforming our world: The 2030 agenda for sustainable development. Resolution adopted by the General Assembly.

Waltz, A. (2016). The women who feed us: Gender empowerment (or lack thereof) in rural Southern Brazil, Journal of Rural Studies, vol 41, 31-40.

World Bank. (2011). Report on Labor participation rate, female (\% of female population ages 15 . 